\title{
Ethnologies
}

\section{Wedding Realities}

The Rules Have Changed... and They Haven't...

\section{Les noces en vrai}

\section{Les règles changent... et restent les mêmes}

\section{Sidney Eve Matrix et Pauline Greenhill}

Volume 28, numéro 2, 2006

Les noces en vrai

Wedding Realities

URI : https://id.erudit.org/iderudit/014981ar

DOI : https://doi.org/10.7202/014981ar

Aller au sommaire du numéro

Éditeur(s)

Association Canadienne d'Ethnologie et de Folklore

ISSN

1481-5974 (imprimé)

1708-0401 (numérique)

Découvrir la revue

Citer ce document

Matrix, S. E. \& Greenhill, P. (2006). Wedding Realities : the Rules Have

Changed... and They Haven't... / Les noces en vrai : les règles changent... et

restent les mêmes. Ethnologies, 28(2), 5-28. https://doi.org/10.7202/014981ar 


\title{
WedDING REALITIES
}

The Rules Have Changed... and They Haven't...

\author{
Sidney Eve Matrix \\ Queen's University \\ Pauline Greenhill \\ University of Winnipeg ${ }^{l}$
}

Many folks think that weddings and marriages are about love and relationships. But love and relationships don't need the institutional verification of the church and/or state that weddings and marriages provide. Ultimately, then, weddings and marriages are actually about sex and property - the socio-religious approval of sex and the socioeconomic distribution, consumption and accumulation of property. Even in the current North American situation, where differences between married and unmarried liaisons are abating, marriage still provides access to health care (or, in Canada, to supplementary health care) not guaranteed to non-married relationships, and grants special immigration status to married partners (see Matrix, forthcoming), not to mention a host of informal social sanctions and approvals. These aims and effects have not changed with the advent of developments from same-sex marriage to writing your own vows to the blatant (or coded) request for cash on the wedding invitation, among other practices that would be unthinkable to most middle class white Euro North Americans as recently as fifty years ago.

Marriage usually refers to the legal and social structures that surround the linking of individuals for the exchange of sexual and economic

1. We would like to express our gratitude to Roewan Crowe, Elizabeth DeWolfe, Holly Everett, Angela Failler, Fiona Green, Kristin Harris-Walsh, Ronald Labelle, Ellen Lewin, Alison Marshall, Michelle Owen, Patricia Sawin, Moshe Shokeid, Michael Taft, Diane Tye, and Linda Watts. 
services. Weddings are the specific legally and religiously sanctioned rituals and ceremonies that actually accomplish that connection. But it is nearly impossible to talk about weddings without saying something about marriage, and vice versa.

Marriage has always implicated the transfer of individuals - usually women - from one kinship line to another - usually between men (see e.g. Lévi-Strauss 1969 and Rubin 1975) — reflected in the Anglo North American tradition of women's surnames changing from their father's to their husband's. ${ }^{2}$ But it has also cross-culturally involved the transfer of actual property - money and gifts - between families and individuals. It may be only upon divorce that many of today's middle class couples discover the link between their wedded state and the sharing of their goods and property, but such co-mingling is present from the moment they are married.

The symbolism of weddings parades the sexualities of the partners; in heterosexual weddings, most obviously that of the bride but also by implication that of the groom. For example, it would be difficult to locate a Euro North American who does not know that white dresses on brides symbolise virginity. It is acceptable to snicker inwardly when the couple has been living together for years, and perhaps even has children together, and the bride chooses to wear white. But even when $\mathrm{s} / \mathrm{he}^{3}$ does not, her/his gown colour decision is a reference to her/his sexuality, whether or not s/he wants it to be. The groom's guiding the bride's hand in cutting the cake is another citation to the initiation into sexuality, as is his/her lifting of the veil, tossing the garter, stamping upon a wineglass, and so on, and so on, and so on. However, as many of the papers here illustrate, the new symbolism of contemporary weddings combines old traditions with new ones: oftentimes today's celebrations are organized around conspicuous consumption of wedding commodities, and the accumulation and display of the correct status goods (such as an exotic honeymoon and elaborate photographic

2. Tellingly, since the 1980s in Québec women and men both keep their original surnames upon marriage.

3. The norm is for brides to be female. However, in a world in which transgendered and transsexual folks rightly seek a place, the norm cannot be presumed. Pauline attended one wedding in the summer of 2006 with two female brides (both women-born-women wearing white gowns and tiaras), and one with one female groom and one male groom (one woman-born-woman wearing a tux and a female to male transperson wearing a tux). 
package) and celebrity designer brands (such as Vera Wang or Krups). These new wedding symbols indicate a couple who is upwardly mobile, propelled by the support, approval and financial investments of their family and friends. Equally, however, marriage and weddings themselves may become optional, replaced by an engagement ceremony before a couple begins living together - or even in the absence of any intention to cohabit.

Etiquette experts concur that it is loutish to point out the economic aspect of weddings. "Miss Jeanne" of www.EtiquetteHell.com unequivocally states: "It's crass and uncouth to discuss money" (Hamilton 2005: 8). It is equally boorish to affirm that marriages are all about legitimising sexual access and what might be the products thereof children. Jeanne Hamilton proclaims: "Some shower hostesses' idea of a good time is... an incredibly crass obsession on the paraphernalia of sexual intercourse" (98-99). But academics are known for reveling in the crass, and thus it should not be surprising that the articles in this special issue, "Wedding Realities," focus a lot more on sex and property than they do on love and relationships.

This collection also addresses in some detail what kinds of property and what kinds of sex are implicated in marriage, because it is in the specifics of sex and property that change in practices and traditions regarding marriage and wedding rituals can be seen most clearly. Sex is often in the forefront of discussions about same-sex marriage; the legitimation of sexual relationships, however, is not always straightforward, as Judith Butler indicates. Being included in society, for hitherto excluded groups like lesbians and gays, can be valuably affirming for individuals. But including some people requires, of necessity, excluding others.

One can see the terrain of the dilemma here: on the one hand, living without norms of recognition result[s] in significant suffering and forms of disenfranchisement that confound the very distinctions among psychic, cultural, and material consequences. On the other hand, the demand to be recognized, which is a very powerful political demand, can lead to new and invidious forms of social hierarchy, to a precipitous foreclosure of the sexual field, and to new ways of supporting and extending state power if it does not institute a critical challenge to the very norms of recognition supplied and required by state legitimation. Indeed, in making a bid to the state for recognition, we effectively restrict the domain of what will become recognizable 
as legitimate sexual arrangements, thus fortifying the state as the source for norms of recognition and eclipsing other possibilities within civil society and cultural life. To demand and receive recognition according to norms that legitimate marriage and delegitimate forms of sexual alliance outside of marriage, or to norms that are articulated in a critical relation to marriage, is to displace the site of delegitimation from one part of the queer community to another or, rather, to transform a collective delegitimation into a selective one.... What [does] it mean to exclude from the field of potential legitimation those who are outside of marriage, those who live nonmonogamously, those who live alone, those who are in whatever arrangements they are in that are not the marriage form (2002: 26-27)?

"Wedding Realities" also attends to the ways that cultural, national, and political contexts are differences that make a huge difference in terms of what can and cannot be found acceptable in marriages and wedding practices. In Canada, legal moves towards legitimising gay and lesbian parenthood, including adoption, actually preceded the legalisation of gay and lesbian marriage in several provinces, including Québec (as early as 1982) and British Columbia (1996). And in the province of Manitoba, for example, there is currently very little difference between a different-sex and a same-sex relationship in the legal context, whether that union is legally solemnised and registered or whether it is formed in common law, as a result (among other legislation) of the Common-Law Partners' Property and Related Amendments Act (S.M. 2002, c. 48). However, in other locations (such as France and Germany), moves to legalise gay and lesbian unions have only gone forward with strict regulation of matters relating to parenthood. "In the French debates on the...'pacts of civil solidarity' that constitute an alternative to marriage for any two individuals unrelated by blood... the passage of the bill finally depended on proscribing the rights of nonheterosexual couples from adopting children and accessing reproductive technology" (Butler 2002: 21-22).

And even the notion of support or lack thereof for same-sex marriage itself cannot be understood in simple binary terms, as Judith Butler again so elegantly puts it.

[I]t may be that one wants to secure the right for those who wish to make use of it even as one does not want it for oneself, or it may be that one wants to counter the homophobic discourses that have been marshaled against gay marriage, but one does not want to be, therefore, in favor of it. Or it may be that one believes very strongly that marriage 
is the best way for lesbian and gay people to go, and would like to install it as a new norm, a norm for the future. Or it may be that one not only opposes it for oneself, but for everybody, and that the task at hand is to rework and revise the social organization of friendship, sexual contacts, and community to produce non-state-centered forms of support and alliance, since marriage, given its historical weight, only becomes an "option" by extending itself as a norm (thus foreclosing options), one which also extends property relations and renders the social forms for sexuality more conservative (Butler 2002: 20-21).

Butler's subject here is same-sex marriage, but her comments attend to the fact that criticism of the structures of marriage is not restricted to people who would have been excluded historically from the right to marry. The availability (or lack thereof) of same-sex marriage has changed the ideological terrain of weddings, without a doubt. However as the rising trend of same-sex wedding trade shows indicates, the existence of same-sex weddings does not necessarily interfere with the commercial impulse behind wedding productions. In fact, the rise of this minority market is a prime opportunity for the wedding industry to sell more paraphernalia, rent more limos, deliver more flowers. From a commercial perspective, same-sex weddings are largely compatible with the existing structure of wedding productions - but from a political vantage point, the shifting terrain of wedding realities is exceptionally threatening to the privileged exclusivity of heterosexual couplings.

To this end, Wendy Pearson details examples of homophobic backlash centring on same-sex marriage, and the myriad of repressive, conservative expressions against the television show "My Fabulous Gay Wedding." The backlash may ultimately be less significant than the relatively mainstreamed presentation of same-sex weddings on TV. And as Pauline Greenhill and Angela Armstrong point out, ideological objections to weddings aren't restricted to those who fail to install heteronormativity and maintain hegemonies. Heterosexual marriages and weddings have always attracted both legal and popular scrutiny and sometimes also legal and popular critique and censure.

Both wedding rituals and the institution of marriage itself are altered somewhat when individuals of the same sex are permitted to participate in it, as Shari Lash suggests - simultaneously arguing strong continuity of purpose and function between conventional and same-sex marriages in the liberal Jewish context. But the changes in wedding practices in Euro North American cultures cannot be linked entirely to same-sex 
marriage. Weddings of any kind are a complex congeries of rules, expectations, trends, mores, and emergent behaviours, explored in detail by Sidney Eve Matrix and Renee Sgroi.

Weddings are also, perhaps inevitably, tremendously conservative. Consider, for example, The Anti-Bride Etiquette Guide: The Rules — and How to Bend Them (Gerin and Hughes 2004). It is worth noting immediately that according to these authors, the rules are meant to be bent, not broken, even by the anti-bride. And the reader avidly seeking alternatives to the financial and emotional complexity of wedding arrangements will find very little in this avowedly — but not actually rule-bending work. The cardinal rule is "it's never okay to ask for money" (140), or, more colourfully, "You should never shake down your guests for wedding costs" (12). At the shower, "Don't suggest 'stock the wedding bar' or 'pass the hat' as a theme for your bridal shower" (12). At the wedding itself, there shall be no cash bar.

This is an offense guests won't forgive or forget. They won't be expecting to pay for anything, especially if they have spent hundreds of dollars on airfare to get to your event. If you can't provide a full bar, then offer beer, wine, champagne punch, and maybe one signature drink. Or invite fewer people, so you can throw a party worth attending (122).

Exchange value - filthy lucre, money - must be absolutely absent from all aspects of the wedding, even to the extent that

under no circumstances is there to be a "tip jar" anywhere near your reception. The coat check folks, bartenders, valet parking attendants, and other service providers who have direct contact with your guests should be made aware that tips will be covered by the hosts and that they should politely decline tips offered by guests (124).

The anti-bride shall decree no "dollar dance".

This Polish custom has each guest pay to dance with the bride or groom at the wedding. The money is intended to help with the honeymoon expenses. This ritual might have a place in Eastern Europe, but not at any wedding we'd attend. Unless you're a daughter of a mob boss, never walk around with a silk pillowcase collecting contributions (or stuff currency of any denomination in your dress) (121). 
Note here the seemingly inevitable cultural confluence between an othered ethnic group and an abhorred practice. Such exercises are, of course, by no means exclusively "Eastern European," and are well known in Anglo strongholds from New Brunswick to British Columbia. For example, wedding receptions in some parts of Anglophone rural southwestern Ontario may include a "money tree" on which guests are expected to pin bills as an anonymous gift to the couple. A Saskatchewan couple, also Anglophone, leaving on their honeymoon received a liquor bottle passed around at their wedding into which guests stuffed bills. During the wedding dance, the bride's shoe may similarly be circulated and filled with cash.

The concept, well-known in Winnipeg, Manitoba, of indicating "presentation" on a wedding invitation, meaning that the couple requests that any gifts come in the form of cash, inspired in "Miss Jeanne" the pinnacle of racist, sexist invective.

The inclusion of "Presentation Preferred" on a wedding invitation is a heinous scheme invented by some greedy, sneaky money-grubber who devised a way to inform guests of her avarice while clothing it in formal language implying that it is proper etiquette. Such highbrow wording gives the impression that this is a more socially suitable method of begging for money than boorishly obvious pleas for cash. In extreme examples of presentation, guests line up at the reception literally to present their monetary gifts to the newlyweds, evoking mental images of the subdued tribes of Africa paying homage to Pharaoh on his throne (Hamilton 2005: 67).

In fact, the anti-bride, like her/his unmarked sister, never actually asks for money at all, from anybody, ever.

When you're in need of a few extra bucks for the nuptials, don't cry poverty to your wealthy relatives. Have a heart-to-heart with your parents. And if you find out that they've received unsolicited offers from the aforementioned rich relatives, let them handle the negotiations, and then follow up with a heartfelt thank-you letter (Gerin and Hughes 2004: 16).

The tendentious focus upon absenting money is particularly ironic given Renee Sgroi's useful treatment of one reality TV wedding as exemplar of the hyperconsumerist imperative of weddings in popular culture. Reality TV wedding discourses, she argues, serve the purpose of inculcating appropriate acquisitive desires in prospective brides and 
grooms. Further, gifts, as the transformation of exchange value into use value, are also firmly rule-governed. The gift registry, critiqued and deconstructed by Sidney Eve Matrix, is particularly fraught with pitfalls. "Even if you're not keen on the idea of registering for gifts, it's always a good idea. Your friends and family will get you something, and it might as well be something that you want! You don't have to limit yourself to flatware; consider registering for anything from power tools to cooking classes to a second car" (Gerin, Hughes, and Hornick 2004: 61). But even the anti-bride can't actually tell guests about her/his registry: "It is just fine to have your maid of honor discreetly get the word out for you. But you can't send out a blanket e-mail to your guests in an effort to commandeer the goods" (Gerin and Hughes 2004: 134).

The wedding itself, even for the anti-bride, is a production spectacular and theatrical. The Anti-Bride Wedding Planner concurs: "A film reel of your wedding has probably been playing in your head ever since you dressed up Barbie and Ken and walked them down the aisle. Now's your chance to star in your own production" (Gerin, Hughes, and Hornick 2004: 5). The bride, then, is not only the producer - the money and logistics person - s/he is also the star — the centre of attention. And s/he's also the director, joining other triple-threat Hollywood types like Kevin Costner and Clint Eastwood. But the guests must not feel that the event is a production. "Do things out of order. Have cocktails and appetizers first, then the ceremony, and then the rest of the party. You'll be able to relax and mingle with your friends. Your guests are more likely to feel included in your wedding, rather than like they're watching a staged production" (71).

A few of the symbolic accoutrements of the wedding have changed: the wedding dress can be red (Gerin and Hughes 2004: 79) and the bridesmaids can wear black (81). The day and venue need not be the conventional one: "A Saturday night in spring or summer is most popular with brides. Consider a Friday night or Sunday afternoon instead" (Gerin, Hughes and Hornick 2004: 6), though they risk the shocked surprise of Pauline's partner's family members about a wedding we were attending: "On a Sunday? At the Art Gallery?" If mere wedding guests are subject to such scrutiny, one wonders what heights of invective might be directed against the bride and groom.

Recall that these rigid rulings are for the anti-bride - the one who wants to "rhumba to the beat of [her/his] own drum" (Gerin, Hughes 
and Hornick 2004: back cover) but doesn't want to do so to "Uncle Bob's polka band" (7). Even those who identify themselves outside the conventional wedding regulation are subjected to the most strict guidelines when addressing one of the two central purposes of the marriage, as already identified: accumulation of property. There are strict rules for conforming and perhaps even more rigid ones describing how a modern ("countercultural") couple can resist the wedding imperatives - but either option involves a considerable outlay of cash, since the hip consumerism of the anti-bride requires purchasing a different set of elaborate, expensive goods and services.

And the guides are mute on the sexual regulation of the anti-bride. Apart from the aforementioned crassness problem, such matters go far beyond etiquette. Indeed, some may not wish their sexuality to be on display for the entire period leading up to and including their wedding day, and choose not to marry at all. Their reasons may vary — from the problem of expecting backlash and negativity to follow their choices of partner (and even of shopping location, as Wendy Pearson's work ironically underlines), to those who feel their relationship(s) is/are beyond scrutiny, to those who couldn't be bothered with the fuss and expense. Yet the contribution by Catherine Arsenault and Martine Roberge, studying the engagements/betrothals of three young Québec women, shows that even not getting married can be attended with extensive ritualisation - even vows, gifts, and community participation.

Yet the elements of the rules, as Renee Sgroi and Sidney Eve Matrix in particular show, are by no means easily apprehended. Popular cultural forms, like the bridal magazine, wedding registry, and TV reality show explicitly instruct bridal consumers about the commodities they should desire to acquire via the wedding production - put differently, they encourage compulsive spending and bridal buying binges. Thus, cultural criticism (Matrix, Pearson, Sgroi) usefully unpacks the discourses of wedding media marketing, deconstructing their seductive consumerist ideologies, while ethnographic work (Arsenault and Roberge, Greenhill and Armstrong, Huang, Lash, Roberge) shows some of the varied ways in which social actors enact their own social dramas in conjunction with these dominant discourses.

The close readings of popular cultural texts provided by Matrix, Sgroi, and Pearson elucidate the many complexities of the "structured structures structuring structures" — to borrow Bourdieu's (in)felicitous 
(1977) phrasing — with which cultural actors must contend, and often contest, or personalize. The more ethnographically focused works of Greenhill and Armstrong and Lash, but particularly Arsenault and Roberge and Xin Huang, show how individuals exercise some creative agency in the face of pre-existing cultural wedding and marriage scripts over which they may appear to exert little control. In her study of a Chinese bride's choices and manipulations of her wedding photograph set, Huang demonstrates the complex negotiations that many a bride will enact while positioning herself simultaneously inside and outside the frame of cultural prescriptives demarcating contemporary wedding realities.

We close with the final note in this issue by Martine Roberge, which directs our hitherto very specific gaze outwards to consider all forms of rituals, particularly those which, like the weddings the other articles address, mark life passages. Her research plan draws attention to the changes in just about every ritual form once characterised as collective, obligatory, structured, fixed, definitive and unique, resulting in a status change that is complete, final, irreversible and formal. Such rituals are being replaced by ones which are polymorphous, reversible, flexible, voluntary and personalised, resulting in a social state which is individualised and deinstitutionalised. And yet, as all the essays in this issue underline, these events are no less significant, no less symbolic, and no less meaningful for participants. 


\section{References}

Bourdieu, Pierre. 1977. Outline of a Theory of Practice. Cambridge: Cambridge University Press.

Butler, Judith. 2002. "Is Kinship Always Already Heterosexual?" Differences: A Journal of Feminist Cultural Studies 13 (1): 14-44.

Cooper, Jennifer. 2001. "Opinion on Common-Law Relationships of Jennifer A. Cooper, Q.C. Volume 1, Final Report of the Review Panel on Common-Law Relationships, December 31. http:/www.gov. $\mathrm{mb} . c a / j u s t i c e /$ publications/commonlawreviewpanel/vol1/3d.html, accessed July 20, 2006.

Gerin, Carolyn and Kathleen Hughes. 2004. Anti-Bride Etiquette Guide: The Rules - and How to Bend Them. San Francisco: Chronicle Books.

Gerin, Carolyn, Kathleen Hughes and Amy Glynn. 2004. Anti-Bride Wedding Planner: Hip Tools and Tips for Getting Hitched. San Francisco: Chronicle Books.

Hamilton, Jeanne. 2005. Wedding Etiquette Hell: The Bride's Bible to Avoiding Everlasting Damnation. New York: St. Martin's Press.

Lévi-Strauss, Claude. 1969. The Elementary Structures of Kinship. Boston: Beacon Press.

Matrix, Sidney. Forthcoming. "Media(ted) Citizenship and Contested Belongings: 'Canadian' War Brides and Fictions of Naturalization." Topia: Canadian Journal of Cultural Studies.

Rubin, Gayle. 1975. "The Traffic of Women: Notes on the Political Economy of Sex." In Rayna R. Reiter ed., Toward an Anthropology of Women: 157-210. New York: Monthly Review. 



\section{LES NOCES EN VRAI}

Les règles changent... et restent les mêmes

\section{Sidney Eve Matrix \\ Queen's University \\ Pauline Greenhill \\ University of Winnipeg $^{l}$}

Beaucoup de gens croient que le mariage et les noces sont affaires d'amour et de relations. Mais l'amour et les relations n'ont pas besoin de la vérification institutionnelle de l'Église et/ou de l'État que confère le mariage. Et puis, en fin de compte, les noces et le mariage sont affaires de sexualité et de propriété - l'approbation socioreligieuse de la sexualité et la répartition, la consommation et l'accumulation socioéconomique de la propriété. Aujourd'hui encore en Amérique du Nord, où les différences entre couples mariés et non-mariés s'estompent, c'est toujours le mariage qui procure l'accès au système de santé (ou, au Canada, au système complémentaire de santé), non garanti aux gens vivant en union libre, et qui confère un statut d'immigrants privilégiés aux partenaires mariés (voir Matrix, à paraître), sans parler d'une foule de sanctions et d'approbations sociales informelles. Ces buts et ces effets n'ont pas changé avec l'avènement de nouveautés, depuis les mariages entre gens du même sexe jusqu'au fait de demander soi-même grossièrement (ou de manière codée) de l'argent sur les cartons d'invitation au mariage, parmi d'autres pratiques qui auraient été impensables pour la plupart des gens de la classe moyenne blanche d'origine européenne en Amérique du Nord il y a à peine cinquante ans.

1. Nous exprimons notre gratitude à Roewan Crowe, Elizabeth DeWolfe, Holly Everett, Angela Failler, Fiona Green, Kristin Harris-Walsh, Ronald Labelle, Ellen Lewin, Alison Marshall, Michelle Owen, Patricia Sawin, Moshe Shokeid, Michael Taft, Diane Tye et Linda Watts. 
Le mariage fait référence d'ordinaire aux structures légales et sociales entourant le lien entre individus pour l'échange de services sexuels et économiques. Les noces sont les rituels et cérémonies spécifiques, la sanction légale et religieuse qui confère sa réalité à cette connexion. Mais il est pratiquement impossible de parler de noces sans dire quelque chose du mariage, et vice versa.

Le mariage a toujours impliqué le transfert d'individus — le plus souvent des femmes - d'un lignage à un autre — le plus souvent entre hommes (voir par exemple Lévi-Strauss 1969 et Rubin 1975) - ce qui se reflète dans la tradition euro-nord-américaine par le fait que les femmes doivent changer le nom de famille qui leur vient de leur père par celui de leur mari². Mais il a aussi mis en jeu, à travers les cultures, le transfert de propriété matérielle — argent et cadeaux — entre les familles et les individus. Il est possible que ce ne soit qu'au moment du divorce que beaucoup de couples de la classe moyenne d'aujourd'hui découvrent le lien entre leur statut matrimonial et le partage de leurs biens et de leurs propriétés, mais un tel entremêlement est factuel à partir du moment où ils sont mariés.

Le symbolisme des noces revient à afficher publiquement les sexualités des partenaires - plus visiblement celle de la mariée dans les noces hétérosexuelles, mais également, par induction, celle du marié. Par exemple, il serait bien difficile de trouver un Euro-Nord-américain qui ignorerait que la robe blanche des mariées symbolise la virginité. On peut ricaner intérieurement lorsque la mariée choisit de porter du blanc alors qu'elle a vécu en couple pendant des années et a peut-être même eu des enfants de son conjoint de fait. Mais même si il/elle ${ }^{3}$ ne le fait pas, le choix de la couleur de sa robe fait référence à sa sexualité, qu'il/elle le veuille ou pas. Que le marié guide la main de la mariée au moment de couper le gâteau est une autre citation de l'initiation à la sexualité, tout comme le fait de soulever le voile, lancer la jarretière, piétiner un verre à vin, et ainsi de suite. Cependant, comme l'illustrent

2. D'où l'effet que produit le Québec, où depuis les années 1980 les femmes, comme les hommes, conservent leur nom de naissance après leur mariage.

3. La norme veut que les mariées soient des femmes. Cependant, dans un monde où des individus «transgenres » ou transsexuels recherchent leur juste place, on ne peut pas présumer de la norme. Au cours de l'été 2006, Pauline a assisté à un mariage avec deux mariées (toutes deux femmes nées femmes portant tiares et robes blanches) et un autre avec un marié-femme et un marié-homme (une femme née femme portant un tuxedo et un transsexuel homme né femme portant un tuxedo). 
beaucoup des articles présentés ici, le nouveau symbolisme des noces contemporaines combine les vieilles traditions et les nouvelles: maintes célébrations d'aujourd'hui s'organisent autour d'une consommation ostentatoire de marchandises spécifiques aux noces, de l'accumulation et de l'exposition de biens statutaires appropriés (tels qu'une lune de miel exotique ou des albums photographiques élaborés) et de marques de designers célèbres (comme Vera Wang ou Krups). Ces nouveaux symboles nuptiaux indiquent que le couple se trouve dans une situation ascensionnelle, poussé de l'avant par le soutien, l'approbation et les investissements financiers de la famille et des amis. Mais le mariage et les noces elles-mêmes peuvent également n'être plus que des options, remplacés par une cérémonie de fiançailles avant qu'un couple commence à vivre ensemble — ou même sans avoir aucunement l'intention de cohabiter.

Certains experts de l'étiquette s'accordent sur le fait qu'il est rustre d'évoquer l'aspect économique des noces. "Miss Jeanne », de EtiquetteHell.com, affirme sans équivoque : «Parler d'argent est lourd et grossier ${ }^{4} »$ (Hamilton $2005: 8$ ). Il est tout aussi malappris d'affirmer que les mariages ont pour objet de légitimer l'accès à la sexualité et à ce qui pourrait en être le produit — les enfants. Jeanne Hamilton proclame : "L'idée d'un bon moment pour quelques hôtesses de showers est... une obsession incroyablement grossière pour l'attirail des rapports sexuels»(2005: 98-99). Mais il est bien connu que les universitaires se délectent de la grossièreté ; aussi cela n'étonnera guère si les articles de ce numéro thématique, «Les noces en vrai » convergent bien plus vers le sexe et la propriété que vers l'amour et les relations.

Ce recueil d'articles interroge aussi en détail quels types de propriété et quels types de sexualité sont impliqués dans le mariage, parce que c'est dans les spécificités de la sexualité et de la propriété que l'on peut voir le plus clairement le changement dans les pratiques et dans les traditions du mariage et des rituels des noces. La sexualité se trouve souvent au premier plan des discussions au sujet des mariages entre personnes du même sexe ; cependant, la légitimation des relations d'ordre sexuel ne coule pas toujours de source, comme l'indique Judith Butler. Pour des groupes jusqu'ici exclus, comme les gais et les lesbiennes, le fait d'être inclus dans la société peut être une précieuse assurance au niveau individuel. Mais le fait d'inclure certaines personnes requiert, par nécessité, que l'on en exclue d'autres.

4. Toutes les traductions de citations sont de la rédaction. 
On peut situer le dilemme ici : d'un côté, vivre sans normes de reconnaissance résulte en souffrance et en formes d'assujettissements entremêlant des conséquences psychiques, culturelles et matérielles ; d'un autre côté, l'exigence d'être reconnu peut mener à de nouvelles formes de hiérarchies sociales enviables, à une abrupte mainmise sur le domaine de la sexualité et à de nouveaux moyens pour le pouvoir étatique d'étendre son emprise, sans parler du fait que cela pourrait porter atteinte aux normes mêmes de reconnaissance fournies et requises pour la légitimation par l'État. En fait, en faisant de la surenchère à la reconnaissance auprès de l'État, nous restreignons en réalité le domaine de ce qui deviendra reconnaissable en tant qu'arrangements sexuels légitimes, fortifiant ainsi l'État en tant que source des normes de reconnaissance et éclipsant les autres possibilités conférées par la société civile et la vie culturelle. Exiger et recevoir de la reconnaissance selon des normes qui légitiment le mariage et délégitiment les formes d'alliance sexuelle en dehors du mariage, ou de normes articulées en une relation critique au mariage, revient à déplacer le lieu de la délégitimation d'une partie de la communauté marginale à une autre ou, plutôt, à transformer une délégitimation collective en une autre, qui serait sélective... Que signifierait exclure du champ de la légitimation potentielle ceux qui vivent en dehors du mariage, ceux qui vivent de manière non monogame, ceux qui vivent seuls, ceux qui se trouvent dans quelque situation que ce soit mais qui n'est pas une forme matrimoniale (2002: 26-27)?

«Les noces en vrai » tient aussi compte du fait que les contextes culturel, national et politique sont des différences qui font une gigantesque différence sur ce qui peut ou ne peut pas être considéré comme acceptable dans les pratiques du mariage et des noces. Au Canada, les mesures législatives allant dans le sens d'une reconnaissance du statut de parents pour les gais et lesbiennes, y compris en ce qui concerne l'adoption, ont en réalité précédé la légalisation du mariage gai et lesbien dans plusieurs provinces, y compris le Québec (aussi tôt que 1982) et la Colombie britannique (1996). Et dans la province du Manitoba, par exemple, il existe aujourd'hui très peu de différences, sur le plan légal, entre une relation hétérosexuelle ou homosexuelle, que cette union soit légalement solennisée et enregistrée ou qu'elle soit simple union de fait, ce qui est le résultat (parmi d'autres promulgations) de la Loi sur les biens des conjoints de fait et modifications connexes (S.M. 2002, c. 48). Cependant, en d'autres endroits (comme en France et en Allemagne), les mesures visant à légaliser les unions des gais et des lesbiennes ne sont pas allées plus loin que la stricte réglementation des questions relatives au statut de parents. «En France, dans les débats sur le... pacte civil de solidarité (PACS), qui constitue une alternative 
au mariage pour deux individus quelconques n'ayant pas de lien de parenté... la promulgation de la loi a tenu en fin de compte à la proscription des droits des couples non hétérosexuels d'adopter des enfants et d'accéder aux technologies de reproduction" (Butler 2002: 21-22).

Et même la notion d'un soutien ou de l'absence de celui-ci aux mariages de même sexe ne peut pas se comprendre simplement en termes binaires, comme Judith Butler, toujours elle, l'expose si élégamment.

Il se peut que l'on veuille obtenir ce droit pour ceux qui veulent l'utiliser, même si ce n'est pas pour soi-même, ou il se peut que l'on veuille contrer les discours homophobes qui ont été alignés contre le mariage homosexuel, mais que l'on ne soit pas soi-même partisan de ce dernier. Ou il se peut que l'on croie fortement que le mariage est ce qu'il y a de meilleur pour les lesbiennes et les gais, et que l'on veuille en faire une nouvelle norme, une norme pour l'avenir. Ou bien il se peut que l'on ne s'y oppose pas seulement pour soi-même, mais pour tout le monde, pensant que la tâche urgente est plutôt de retravailler et de réviser l'organisation sociale de l'amitié, des contacts sexuels et de la communauté afin de produire des formes non étatiques de soutien et d'alliances puisque le mariage, étant donné son poids historique, ne devient un "choix » que parce qu'il s'est étendu jusqu'à être la norme (mettant fin ainsi aux autres choix), qui s'étend aussi aux relations de propriété et rend les autres formes sociales de la sexualité plus conservatrices (Butler 2002: 20-21).

Le sujet de Butler est ici le mariage entre personnes du même sexe, mais ses commentaires prennent en compte le fait que la critique des structures du mariage n'est pas restreinte aux gens qui auraient été exclus historiquement du droit de se marier. La possibilité (ou l'impossibilité) des mariages entre personnes de même sexe a sans aucun doute modifié le terrain idéologique des noces. Cependant, ainsi que l'indique la tendance grandissante à faire des mariages entre gens du même sexe des spectacles commerciaux, l'existence de ces mariages ne contrecarre pas forcément l'impulsion commerciale à l'arrière-plan de l'appareil des noces. En fait, l'apparition de ce marché minoritaire constitue une occasion majeure pour l'industrie du mariage de vendre plus d'attirail, de louer plus de limousines, de livrer plus de fleurs. D'un point de vue commercial, les mariages entre personnes du même sexe sont tout à fait compatibles avec les structures existantes de productions destinées aux mariages - mais, du point de vue plus élevé de la politique, les terrains glissants des noces d'aujourd'hui menacent grandement les privilèges exclusifs des appariements hétérosexuels. 
Dans ce but, Wendy Gay Pearson détaille les exemples d'un retour de bâton homophobe au sujet des mariages entre personnes de même sexe et de la myriade d'expressions répressives et conservatrices à l'encontre de l'émission télévisée «My Fabulous Gay Wedding ». Ce retour de bâton pourrait en fin de compte s'avérer moins significatif que la représentation relativement consensuelle des mariages entre personnes du même sexe à la télévision. Et comme le font remarquer Pauline Greenhill et Angela Armstrong, les objections idéologiques aux noces ne se limitent pas seulement à celles qui font vaciller l'héréronormativité et le maintien des hégémonies. Les mariages et les noces hétérosexuels ont toujours fait l'objet de l'attention législative et populaire - et ont parfois également attiré la critique et la censure législatives et populaires.

Tant les rituels des noces que l'institution du mariage elle-même sont parfois quelque peu altérés lorsque des individus du même sexe se voient accorder le droit d'y participer, comme le suggère Shari Lash qui, simultanément, soutient qu'il existe une forte continuité d'intentions et de fonction entre les mariages conventionnels et ceux entre personnes du même sexe dans le contexte juif libéral. Mais les changements dans les pratiques nuptiales dans les cultures euro-nord-américaines ne peuvent pas être exclusivement liées aux mariages entre personnes du même sexe. Toutes les formes de noces constituent un amas complexe de règles, d'attentes, de tendances, de moeurs et de comportements émergents, que Sidney Eve Matrix et Renee Sgroi explorent en détail.

Les noces sont aussi, inévitablement peut-être, démesurément conservatrices. Que l'on considère par exemple The Anti-Bride Etiquette Guide: The Rules — and How to Bend Them [Le guide de savoir-viure de l'anti-mariée. Les règles, et comment les contourner] (Gerin et Hughes 2004). Il vaut la peine de noter immédiatement que selon ces auteurs, les règles sont faites pour être contournées, non pas brisées, même par une «anti-mariée ». Et le lecteur désireux de découvrir des alternatives à la complexité financière et émotionnelle des préparatifs de mariage trouvera peu de choses dans ce qui se déclare - mais n'est pas réellement - un travail de contournement des règles. La règle cardinale est « il n'est jamais correct de demander de l'argent»(140), ou, de manière plus colorée, «vous ne devriez jamais secouer vos invités pour leur faire payer la noce»(12). Au moment du shower, "ne suggérez pas pour thème "Faites passer le chapeau" ou "Approvisionnez le bar de la noce" » (12). Lors de la noce elle-même, il ne devrait pas y avoir de bar payant. 
C'est une insulte que vos hôtes n'oublieront ni ne vous pardonneront. Ils ne s'attendront pas à payer pour quoi que ce soit, surtout s'ils ont dépensé des centaines de dollars en billets d'avion pour assister à l'évènement. Si vous ne pouvez pas fournir un bar complet, eh bien, proposez de la bière, du vin, un punch au champagne et peut-être un cocktail spécial. Ou invitez moins de gens, pour pouvoir préparer une soirée pour laquelle cela vaudra la peine de s'être déplacé (122).

Les valeurs monétaires - l'appât du gain — doivent être absolument absentes de tous les aspects de la noce, jusqu'au point où

sous aucun prétexte il ne doit y avoir d'assiette à pourboires dans votre réception. Le personnel d'accueil, les barmans, les valets de parking et les autres fournisseurs de services ayant un contact direct avec vos invités doivent être prévenus que les pourboires seront donnés par ceux qui reçoivent et qu'ils doivent poliment refuser les pourboires offerts par les invités (124).

L'anti-mariée doit décréter qu'il n'y aura aucune « danse du dollar ».

Dans cette coutume polonaise, chaque invité paie pour danser ave la mariée ou avec le marié. L'argent est destiné aux dépenses de la lune de miel. Ce rituel a peut-être une place en Europe de l'Est, mais à aucun des mariages auxquels nous avons assisté. À moins que vous ne soyez la fille d'un caïd de la pègre, ne vous promenez jamais avec une taie d'oreiller en soie pour recueillir les contributions (non plus que du numéraire de n'importe quelle sorte dans votre robe) (121).

Relevons ici l'assimilation culturelle apparemment inévitable entre un groupe ethnique réduit à son altérité et une pratique abhorrée. De telles pratiques ne sont en aucun cas bien sûr exclusivement « de l'Europe de l'Est» et sont bien connues dans les places fortes anglophones, depuis le Nouveau-Brunswick jusqu'à la Colombie britannique. Par exemple, en certains lieux de l'Ontario anglophone du sud-ouest, il peut y avoir dans certaines noces un " arbre à monnaie » sur lequel on s'attend à ce que les invités épinglent des billets et des cadeaux anonymes pour le couple. Un couple de la Saskatchewan, lui aussi anglophone, en partance pour sa lune de miel, reçut une bouteille de soda que l'on avait passée à la ronde au cours de la noce et dans laquelle les invités avaient glissé des billets. On peut aussi, pendant les danses de la noce, faire circuler la chaussure de la mariée et la remplir d'argent.

La pratique bien connue à Winnipeg, Manitoba, d'écrire le mot «presentation» sur un carton d'invitation, signifiant que le couple 
demande que tous les cadeaux soient faits sous forme monétaire, a inspiré à «Miss Jeanne » un summum d'invectives racistes et sexistes.

La mention «presentation de préférence » sur un carton d'invitation est une abominable combine inventée par quelque grippe-sou avide et sournois qui a trouvé le moyen de faire connaître sa cupidité à ses invités tout en l'habillant du langage formel impliquant que cela se fait. Une expression si pensée donne l'impression qu'il s'agit d'une méthode plus socialement convenable de demander de l'argent que d'autres prétextes, évidents et grossiers. Dans certains exemples extrêmes de "presentation", les invités font la queue à la réception, pour présenter littéralement leurs cadeaux monétaires aux nouveaux mariés, évoquant les images mentales des tribus soumises d'Afrique remettant leurs tributs au pharaon sur son trône (Hamilton 2005 : 67).

En fait, l'anti-mariée, à l'instar de son homologue non démarquée, ne demande pas d'argent du tout, de personne, jamais.

Si vous avez besoin de quelques billets de plus pour les noces, n'allez pas pleurer misère auprès des membres aisés de votre famille. Parlezen à coeur ouvert avec vos parents. Et si vous découvrez que quelquesuns d'entre eux ont déjà spontanément proposé d'offrir quelque chose, laissez-les se charger des négociations, puis rédigez ensuite une chaleureuse lettre de remerciements (Gerin et Hughes $2004: 16$ ).

Cette focalisation tendancieuse sur la mise à l'écart de l'argent est particulièrement ironique si l'on considère l'utile analyse que fait Renee Sgroi d'un mariage de "télé-réalité » en tant qu'exemple des impératifs d'hyperconsumérisme liés aux noces dans la culture populaire. Elle soutient que les discours relatifs aux noces, dans la télé-réalité, ont pour finalité d'inculquer les désirs appropriés d'acquisition chez les futurs mariés. De plus, les cadeaux, ainsi que la transformation de la valeur d'échange en valeurs d'usage, sont également fermement réglementés. La liste de mariage, que critique et déconstruit Sidney Eve Matrix, est particulièrement piégée. "Même si vous n’êtes pas très chaud sur le principe d'une liste de mariage, c'est toujours une bonne idée. Vos amis et votre famille vous offriront quelque chose, alors autant que ce soit quelque chose que vous désirez! Vous n'avez pas à vous limiter à des assiettes; pensez à inscrire toutes sortes de choses sur la liste, depuis des outils électriques, des cours de cuisine ou une deuxième voiture » (Gerin, Hughes et Hornick 2004 : 61). Mais même l'anti-mariée ne peut pas vraiment parler à ses invités de sa liste de mariage : "C'est très bien si votre demoiselle d'honneur peut passer le mot pour vous. Mais vous ne pouvez pas envoyer une circulaire par courriel à vos invités pour imposer vos requêtes»(Gerin et Hughes 2004 : 134). 
La noce elle-même, y compris pour l'anti-mariée, est un film spectaculaire et théâtral. L'Anti-Bride Wedding Planner renchérit : «Le film de vos noces défile probablement dans votre tête depuis que vous vous êtes déguisés en Barbie et Ken pour marcher vers l'autel. À présent vous avez la chance d'être la vedette de votre propre production » (Gerin, Hughes et Hornick 2004 : 5). Le marié ou la mariée n'est donc plus seulement le producteur - en charge de l'argent et de la logistique —, il ou elle est aussi la vedette — le centre de l'attention. Et il ou elle est aussi le réalisateur, rejoignant d'autres figures hollywoodiennes à triple casquette comme Kevin Costner et Clint Eastwood. Mais les invités ne doivent pas avoir l'impression que l'événement est un film. "Faites les choses dans le désordre. Servez d'abord les cocktails et les amuse-gueules, ensuite la cérémonie, et enfin le reste de la réception. Vous serez capables de vous détendre et de vous mêler à vos amis. Vos invités auront davantage l'impression d'être inclus dans la noce, plutôt que de simplement regarder un spectacle mis en scène » $(71)$.

Quelques-uns des affublements symboliques du mariage ont changé : la robe de mariée peut être rouge (Gerin et Hughes 2004 : 79) et les demoiselles d'honneur peuvent porter du noir (81). Le jour et le lieu n'ont plus à être conventionnels : «Les mariés préfèrent le plus souvent un samedi soir au printemps ou en été. Pensez plutôt à un vendredi soir ou à un dimanche après-midi »(Gerin, Hughes et Hornick 2004 : 6), bien que cela risque de susciter le même type de surprise outrée que dans la famille du partenaire de Pauline au sujet d'un mariage auquel nous assistions: «Un dimanche? Au musée?» Si de simples invités au mariage peuvent faire l'objet d'une telle observation, on se demande quelles proportions peuvent atteindre les sarcasmes à l'encontre des mariés.

Rappelons-nous que ces règlements sont rigides pour l'anti-mariée - celui ou celle qui veut «danser au rythme de son propre tambour» (Gerin, Hughes et Hornick 2004 : quatrième de couverture) et pas sur «les polkas de l'oncle Bob» (7). Même ceux qui se considèrent affranchis des règles conventionnelles des noces sont assujettis aux plus strictes des conventions lorsque l'on en vient à l'une des deux finalités centrales du mariage, comme nous les avons déjà identifiées: l'accumulation de propriété. Il y a des règles sévères auxquelles il faut se conformer et d'autres, peut-être encore plus rigides, servant au couple moderne, de la «contre-culture », à démontrer comment il résiste aux 
impératifs des noces - mais l'un ou l'autre choix implique des dépenses considérables, puisque le consumérisme pointu de l'anti-mariée exige qu'il ou elle recherche un ensemble différent de biens et services coûteux.

Et les guides sont muets en ce qui concerne les règlements relatifs à la sexualité de l'anti-mariée. À l'exception de ce problème de grossièreté mentionné plus haut, de telles questions vont bien au-delà de l'étiquette. En fait, certains ne veulent pas voir leur sexualité exposée pendant toute la période allant jusqu'au jour de leur mariage, ce jour-là y compris, et choisissent de ne pas se marier du tout. Leurs raisons peuvent varier - crainte de réactions violemment négatives en ce qui concerne leur choix de partenaire (voire même leur choix de boutiques, comme le travail de Wendy Gay Pearson le souligne ironiquement), sentiment que la relation du couple est au-delà du regard des autres, ou volonté de ne pas s'encombrer de tout ce raffut et de toutes ces dépenses. Cependant, la contribution de Catherine Arsenault et Martine Roberge, étudiant les fiançailles de trois jeunes Québécoises, montre que même le fait de ne pas se marier peut être intensément ritualisé — avec des vœux, des cadeaux et une participation communautaire.

Mais les éléments des règles, comme le montrent en particulier Renee Sgroi et Sidney Eve Matrix, ne sont en aucun cas faciles à appréhender. Les formes de la culture populaire comme les magazines spécialisés, les listes de mariage et les spectacles de télé-réalité enseignent explicitement aux aspirants au mariage quels biens ils devraient désirer acquérir lors du déroulement du «film de leurs noces » — en d'autres termes, ils encouragent les dépenses compulsives et les débauches d'achats nuptiaux. Aussi la critique culturelle (Matrix, Pearson, Sgroi) est-elle utile pour déballer les discours de la mise en marché médiatique des noces et pour déconstruire leurs séduisantes idéologies consuméristes, tandis que le travail ethnographique (Arsenault et Roberge, Greenhill et Armstrong, Huang, Lash, Roberge) montre quelques-unes des différentes manières par lesquelles les acteurs sociaux jouent leurs propres dramatiques sociales en conjonction avec ces discours dominants.

La lecture attentive de textes de culture populaire que font Matrix, Sgroi et Pearson éclaire quelques-unes des nombreuses complexités de ces « structures structurées structurant les structures » - pour emprunter l'expression (mal)heureuse de Bourdieu (1977) — auxquelles les acteurs culturels ont affaire et qu'ils doivent souvent contester ou personnaliser. Les travaux plus proprement ethnographiques de Greenhill et Armstrong 
et Lash, et en particulier d'Arsenault et Roberge et Xin Huang, montrent comment les individus exercent un certain agir créatif devant les scénarios culturels préexistants des noces et du mariage sur lesquels ils semblent n'avoir que peu de contrôle. Dans son étude des manipulations et des choix faits par une Chinoise lors de sa séance de photographies de mariage, Huang démontre les négociations complexes que plus d'une mariée devra mettre en œuvre pour se placer simultanément à l'intérieur et à l'extérieur du cadre des impératifs culturels encadrant les réalités des noces contemporaines.

Martine Roberge conclut ce volume en dirigeant notre regard jusqu'ici très spécifique vers d'autres formes de rituels, en particulier ceux qui, comme les noces qu'évoquaient les autres articles, marquent des passages. Son projet de recherche attire l'attention sur les changements qui interviennent dans pratiquement toutes les formes rituelles autrefois caractérisées comme collectives, obligatoires, structurées, fixes et uniques, et aboutissant à un changement de statut intégral, définitif, irréversible et formel. De tels rituels sont remplacés par d'autres, polymorphes, réversibles, flexibles, volontaires et personnalisés, aboutissant à un état social individualisé et désinstitutionnalisé. Et cependant, comme le soulignent tous les articles de ce volume, ces évènements n'en sont pas moins porteurs de sens et symboliques pour les participants. 


\section{Références}

Bourdieu, Pierre, 1977, Outline of a Theory of Practice. Cambridge, Cambridge University Press.

Butler, Judith, 2002, «Is Kinship Always Already Heterosexual?»

Differences. A Journal of Feminist Cultural Studies 13 (1): 14-44.

Cooper, Jennifer, 2001. «Opinion on Common-Law Relationships of Jennifer A. Cooper, Q.C. Volume 1, Final Report of the Review Panel on Common-Law Relationships, December $31 »$. http:// www.gov.mb.ca/justice/publications/commonlawreviewpanel/vol1/ 3d.html, site consulté le 20 juillet 2006.

Gerin, Carolyn et Kathleen Hughes, 2004, Anti-Bride Etiquette Guide.

The Rules - and How to Bend Them. San Francisco, Chronicle Books.

Gerin, Carolyn, Kathleen Hughes et Amy Glynn, 2004, Anti-Bride Wedding Planner. Hip Tools and Tips for Getting Hitched. San Francisco, Chronicle Books.

Hamilton, Jeanne, 2005, Wedding Etiquette Hell. The Bride's Bible to Avoiding Everlasting Damnation. New York, St. Martin's Press.

Lévi-Strauss, Claude, 1969, The Elementary Structures of Kinship. Boston, Beacon Press.

Matrix, Sidney, à paraître, "Media(ted) Citizenship and Contested Belongings. "Canadian" War Brides and Fictions of Naturalization ». Topia. Canadian Journal of Cultural Studies.

Rubin, Gayle, 1975, «The Traffic of Women. Notes on the Political Economy of Sex ». Dans Rayna R. Reiter, (dir.), Toward an Anthropology of Women. New York, Monthly Review : 157-210. 